\title{
A PUZZLING MIGRATORY DETOUR: ARE FUELING CONDITIONS IN ALASKA DRIVING THE MOVEMENT OF JUVENILE SHARP-TAILED SANDPIPERS?
}

\author{
Åke Lindström ${ }^{1}$, Robert E. Gill Jr. ${ }^{2}$, SArah E. Jamieson ${ }^{3,9}$, Brian McCaffery $^{4}$, \\ Liv Wennerberg ${ }^{5,10}$, Martin Wikelski $^{6}$, And Marcel KlaAssen $7,8,11$ \\ ${ }^{1}$ Department of Biology, Animal Ecology, Lund University, Ecology Building, S-223 62 Lund, Sweden \\ ${ }_{2}^{2}$ Alaska Science Center, U.S. Geological Survey, 4210 University Dr., Anchorage, AK 99508 \\ ${ }^{3}$ Centre for Wildlife Ecology, Simon Fraser University, 8888 University Dr., Burnaby, BC V5A 1S6, Canada \\ ${ }^{4}$ U.S. Fish and Wildlife Service, Yukon Delta National Wildlife Refuge, P.O. Box 346, Bethel, AK 99559 \\ ${ }^{5}$ Natural History Museum, University of Oslo, P.O. Box 1172, Blindern, NO-0318 Oslo, Norway. \\ ${ }^{6}$ Department of Migration and Immuno-ecology, Vogelwarte Radolfzell, Max-Planck Institute for Ornithology, \\ D-78315 Radolfzell, Germany \\ ${ }^{7}$ Netherlands Institute of Ecology, NIOO-KNAW, Rijksstraatweg 6, NL-3631 AC Nieuwersluis, the Netherlands \\ ${ }^{8}$ Centre for Integrative Ecology, Deakin University, Waurn Ponds Campus, Geelong, Victoria 3217, Australia
}

Abstract. Making a detour can be advantageous to a migrating bird if fuel-deposition rates at stopover sites along the detour are considerably higher than at stopover sites along a more direct route. One example of an extensive migratory detour is that of the Sharp-tailed Sandpiper (Calidris acuminata), of which large numbers of juveniles are found during fall migration in western Alaska. These birds take a detour of 1500-3400 km from the most direct route between their natal range in northeastern Siberia and nonbreeding areas in Australia. We studied the autumnal fueling rates and fuel loads of 357 Sharp-tailed Sandpipers captured in western Alaska. In early September the birds increased in mass at a rate of only $0.5 \%$ of lean body mass day ${ }^{-1}$. Later in September, the rate of mass increase was about $6 \%$ of lean body mass day ${ }^{-1}$, among the highest values found among similar-sized shorebirds around the world. Some individuals more than doubled their body mass because of fuel deposition, allowing nonstop flight of between 7100 and $9800 \mathrm{~km}$, presumably including a trans-oceanic flight to the southern hemisphere. Our observations indicated that predator attacks were rare in our study area, adding another potential benefit of the detour. We conclude that the most likely reason for the Alaskan detour is that it allows juvenile Sharp-tailed Sandpipers to put on large fuel stores at exceptionally high rates.

Key words: Calidris acuminata, migration, waders, body mass, fat stores, predation, age-segregated migration, Alaska.

Un Desvío Migratorio Desconcertante: ¿Están las Condiciones de Abastecimiento en Alaska Conduciendo los Movimientos de los Jóvenes de Calidris acuminata?

Resumen. Hacer un desvío puede ser ventajoso para un ave migratoria si las tasas de abastecimiento de combustible en los sitios de parada a lo largo del desvío son considerablemente mayores que las de los sitios de parada a lo largo de una ruta más directa. Un ejemplo de un gran desvío migratorio es el de Calidris acuminata: un gran número de individuos jóvenes de esta especie se hallan en el oeste de Alaska durante la migración de otoño. Estas aves toman un desvío de 1500-3400 km de la ruta más directa entre sus áreas natales en el noreste de Siberia y las áreas no reproductivas en Australia. Estudiamos las tasas de abastecimiento otoñales y las cargas de combustible de 357 individuos de C. acuminata capturados en el oeste de Alaska. A principios de septiembre las aves aumentaron su masa a una tasa de sólo $0.5 \%$ de masa corporal magra por día. Más tarde en septiembre, la tasa de aumento de masa fue del 6\% de masa corporal magra por día, que se ubica entre los valores más altos encontrados para aves playeras de tamaño similar alrededor del mundo. Algunos individuos aumentaron su masa corporal a más del doble debido al abastecimiento de combustible, permitiendo un vuelo sin escalas de entre 7100 y 9800 $\mathrm{km}$, presumiblemente incluyendo un vuelo transoceánico al hemisferio sur. Nuestras observaciones indicaron que los ataques de depredadores fueron raros en nuestra área de estudio, agregando otro beneficio potencial al desvío. Concluimos que la razón más probable de los desvíos de Alaska es que le permite a los jóvenes de C. acuminata obtener reservas de combustible grandes a tasas excepcionalmente altas.

Manuscript received 10 September 2009; accepted 4 August 2010.

${ }^{9}$ Current address: Ecology Group, Institute of Natural Resources, Massey University, Private Bag 11222, Palmerston North, New Zealand.

${ }^{10}$ Current address: Buskerud fylkeskommune, Fylkeshuset, NO-3020 Drammen, Norway.

${ }^{11}$ E-mail: marcel.klaassen@ deakin.edu.au

The Condor, Vol. 113, Number 1, pages 129-139. ISSN 0010-5422, electronic ISSN 1938-5422. @ 2011 by The Cooper Ornithological Society. All rights reserved. Please direct all requests for permission to photocopy or reproduce article content through the University of California Press's Rights and Permissions website, http://www.ucpressjournals.com/ reprintInfo.asp. DOI: $10.1525 /$ cond.2011.090171 


\section{INTRODUCTION}

Many shorebirds breeding in the Arctic make spectacular migrations between breeding grounds on northern tundra and distant nonbreeding grounds in the Southern Hemisphere. Adults and juveniles of most migratory birds, including shorebirds, normally follow the same migration routes. Along these routes they rely on food-rich stopover sites for successful fueling (Alerstam 1990). In shorebirds, the timing of fall migration of the age classes often differs, adult birds migrating several weeks earlier than juveniles (Kolthoff 1896, Alerstam 1990, Ydenberg et al. 2004). Accordingly, most juveniles migrate without guidance from experienced conspecifics.

There is one striking exception to the rule that adult and juvenile arctic shorebirds follow the same migration route (Fig. 1). Adult Sharp-tailed Sandpipers (Calidris acuminata) migrate from their breeding grounds in northeast Russia on a course due south toward their wintering grounds in Australia (Higgins and Davies 1996, Handel and Gill 2010). A substantial proportion of the juveniles, however, including at least thousands and possibly tens of thousands of birds, first makes a detour east to western Alaska (Gill and Handel 1981, Handel and Gill 2010). The birds start to appear in late August and stay for about a month to fuel up for southward migration (Gill and Handel 1981). They then continue south to the Australian nonbreeding range, most likely after a nonstop flight across the Pacific Ocean (Handel and Gill 2010). From the longitudinal midpoint of the breeding range (Higgins and Davies 1996), Alaska lies $2300 \mathrm{~km}$ due east along a greatcircle route. Why do juvenile Sharp-tailed Sandpipers make this long detour via Alaska during their first fall migration? At first glance, there are several apparent obstacles to the evolution of such a migration strategy.

First, all else being equal, adding a $2300-\mathrm{km}$ trip requires a substantial extra investment of time and energy, both of which may be limited resources for migrants (Alerstam and Lindström 1990). Second, once in Alaska, the juvenile birds may make a trans-oceanic migration (Handel and Gill 2010), which can be achieved only by putting on extraordinarily large fuel loads (cf. Piersma and Gill 1998, Battley et al. 2000, Gill et al. 2009). Large fuel loads require stopover sites that allow for very high fueling rates so that the fuel necessary for departure can be loaded before the interval optimal for migration passes. Third, because birds with larger stores of fuel are likely to be more vulnerable when attacked by predators (Kullberg et al. 1996, Burns and Ydenberg 2002), the sites at the end of such a detour should ideally be less dangerous (sensu Lank and Ydenberg 2003) for staging birds. Fourth, Alerstam et al. (2001) claimed that migratory flights along a west-east axis in the Bering Strait area may be particularly complicated with respect to orientation because of the complex pattern of the magnetic field in this area (caused by the proximity to the north magnetic pole) and the time shifts associated with rapid longitudinal displacement, which complicate the use of a sun compass. Given that orientation in general can be a challenge for migrants, we should therefore expect natural selection to act against the evolution of such a potentially complicated flight route (as compared to the more direct southerly route that the adults take). Fifth, the route-specific experience the juveniles gather along their first fall migration will be of no use later in life, unlike birds that follow the same route all their lives.

But detours (i.e., extended flights away from the main axis of migration) could also be selected for. Alerstam (2001) concluded that detours can be favorable for time-minimizing migrants, if fuel-deposition rates at stopover sites along the detour are higher than at stopover sites along a more direct route, to such an extent that they outweigh the cost of the added time associated with the longer flight. We do not know whether juvenile Sharp-tailed Sandpipers are time minimizers, but the fact that they, like many other shorebirds, must cover huge distances during migration strongly suggests a premium on fast migration (cf. Gudmundsson et al. 1991, Lindström et al. 2002). Finding stopover sites with lower predation pressure could also be a reason for a migratory detour. Predation on migrants during stopover can indeed be substantial (Lindström 1989, Bélisle and Giroux 1995, Ydenberg et al. 2004), and the danger of predation may well shape migratory behavior (Alerstam and Lindström 1990, Ydenberg et al. 2004, Pomeroy et al. 2008).

We studied the fuel loads and fueling rates of juvenile Sharp-tailed Sandpipers in fall in western Alaska. In light of the potential time and energy constraints acting upon birds making a long migratory detour, we expected to find very high fueling rates. We also address the level of predation danger the birds experience during stopover in Alaska.

\section{METHODS}

Our study took place on the outer Yukon-Kuskokwim delta, Alaska, primarily as part of the Swedish-American-Russian expedition "Beringia 2005" (Rickberg 2006). The YukonKuskokwim delta hosts large numbers of shorebirds of various species during stopover (Gill and Handel 1990), including Sharp-tailed Sandpipers that normally appear in the area beginning the last 10 days of August and peak in numbers in mid-September (Handel and Gill 2010). Most of our work was focused at three sites, all within the Yukon Delta National Wildlife Refuge (Fig. 1). The principal site was near the mouth of the Tutakoke River $\left(61^{\circ} 14.43^{\prime} \mathrm{N}, 165^{\circ} 38.03^{\prime} \mathrm{W}\right)$ on Angyoyaravak Bay along the Bering Sea coast; we did additional work farther inland at Old Chevak, $22 \mathrm{~km}$ to the NNE of Tutakoke, and at Kanaryarmiut Field Station, $30 \mathrm{~km}$ ENE of Tutakoke (Fig. 1). Descriptions of the three sites appear in Handel and Gill (1992), McCaffery et al. (2008), and Nebel and McCaffery (2003), respectively. Observers were in the field from 1 to 13 September 2004, 1 August to 26 September 2005, and 11 August to 20 September 2006. We trapped 


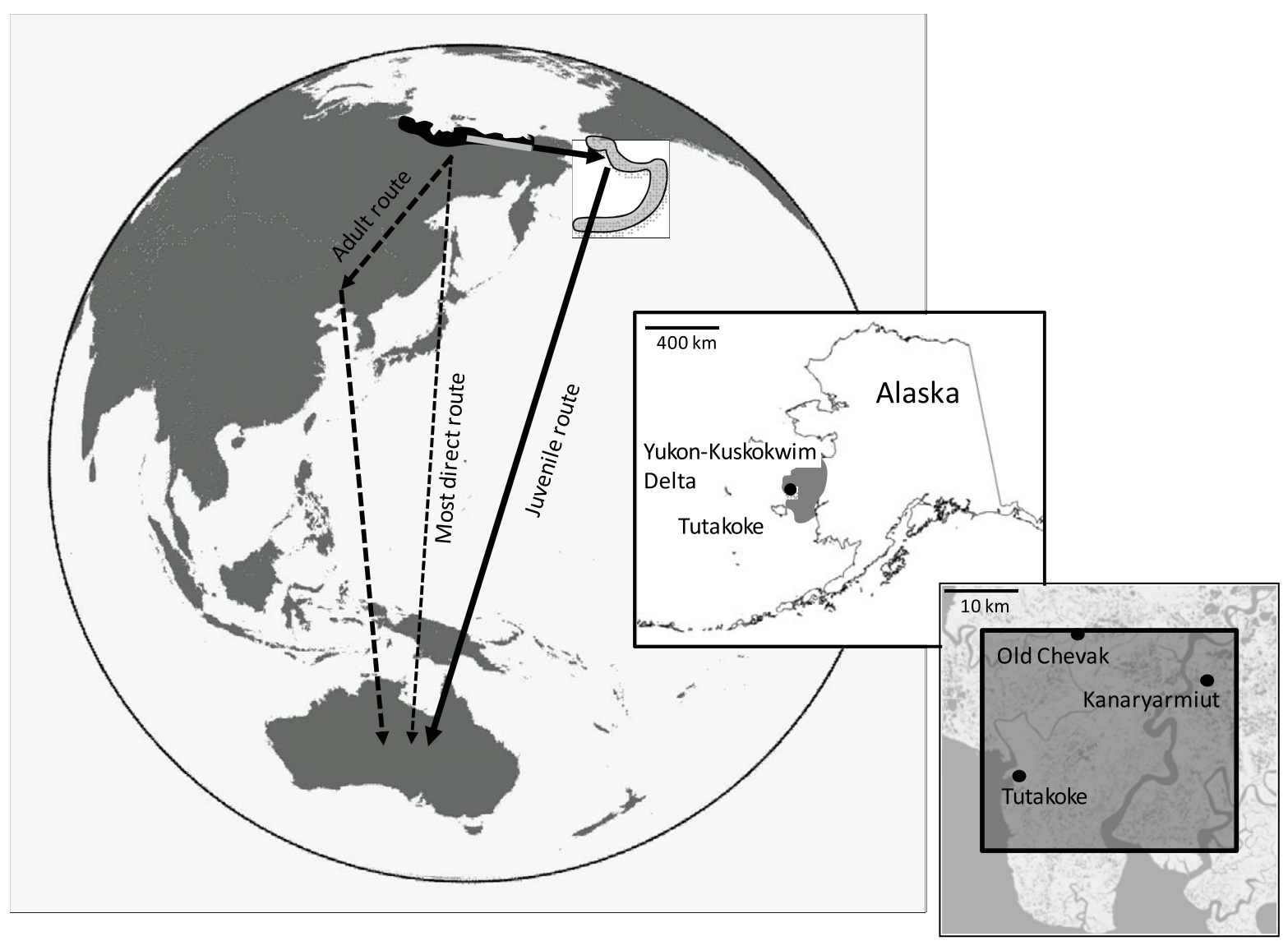

FIGURE 1. Location of seasonal events for the Sharp-tailed Sandpiper: nonbreeding (light shading, encompassing mainly Australia, New Zealand and New Guinea ), breeding (dark shading), autumn staging of juveniles (intermediate shading in Alaska), and the presumed routes taken between them. The solid lines depict juveniles' presumed routes from the breeding range to the sites of fall staging in Alaska $(\sim 2500 \mathrm{~km})$ and subsequently from the staging grounds to the nonbreeding grounds $(\sim 10300 \mathrm{~km})$. Dashed lines depict adults' presumed routes $(\sim 3600$ and $7300 \mathrm{~km})$. The central thin line depicts the most direct route between breeding and nonbreeding ranges $(\sim 10300 \mathrm{~km})$. Seasonal ranges and routes are according to Kessel and Gibson (1978), Tomkovich (1992), Higgins and Davies (1996), Handel and Gill (2010). The two insets depict details of the study area, including the area of $30 \times 35 \mathrm{~km}$ within which our aerial surveys were made (dark shading).

Sharp-tailed Sandpipers at Tutakoke, Old Chevak, and Kanaryarmiut Field Station in 2004 and at Tutakoke and Kanaryarmiut Field Station in 2005. We trapped birds either in portable and folding walk-in traps (“Ottenby" traps, $120 \times 35$ $\times 35 \mathrm{~cm}$, Lindström et al. 2005) or on a few occasions in mist nets with tape lures. Within an hour of capture, all birds were banded with metal and, in 2005, color bands, then weighed to the nearest $0.1 \mathrm{~g}$ with a Pesola spring balance or an electronic balance. We scored visible fat in the interclavicular pit (range 0-9) on an extended version of the scale of Pettersson and Hasselquist (1985), but also see Lindström (1998). Fat was always scored before the bird was weighed. In 2005, because of two large floods at the coastal site (Tutakoke), we could devote much less time to trapping in the second half of September than in the first half.

Using calipers, we recorded the following measurements (to the nearest $0.1 \mathrm{~mm}$ ): bill from tip to farthest point of exposed, nonfeathered culmen, total head length from bill tip to back of skull (Green 1980), and tarsus, with the toes and tibiotarsus held perpendicular to the tarsometatarsus, measuring the distance between the extreme points of bending (Alatalo and Lundberg 1986). We used a stopped ruler to measure (nearest $1 \mathrm{~mm}$ ) the length of the flattened wing, from the carpal joint to the tip, and foot, from the back of the tarsal joint to tip of the longest toe (Piersma 1984).

We wanted to confirm existing evidence for sexual size dimorphism in the Sharp-tailed Sandpiper (Higgins and Davies 1996) by sexing some birds with molecular markers, potentially allowing us to use morphometrics for sexing of birds in the hand. For molecular sexing (at the Natural History Museum, University of Oslo, Norway), we took about 20-30 $\mu \mathrm{L}$ of blood from a random subset of these birds and kept it in Longmire buffer. We extracted DNA from the blood samples with a QIAmp DNA Mini kit (Qiagen), then sexed the birds by standard PCR methods, using primers P2 and P8 (Griffiths et al. 1998). The bands were separated by gel electrophoresis 
in $2 \%$ agarose gels, stained with ethidium bromide, and visualized under UV light. We compared the lengths of the bands to a size marker (1-kb DNA ladder, Life Technologies).

Because we recaptured no birds in 2004, we could not determine if apparent mass changes through time were the result of individual birds accumulating weight over a period of residency in the study areas and/or birds with different mean masses simply arriving later during the migration period. To address this issue in 2005 and verify whether we were sampling body masses over time from a virtually closed population, we attempted to determine length of stay by equipping 30 birds with BD-2 transmitters (Holohil Systems, Ltd.) with a mass of $1.8 \mathrm{~g}$ and an expected battery life of 6 weeks. To distinguish between the radio signals of the individual birds, the transmitters were built to transmit pulses at one of three rates $(0.8,1.0$, and $1.4 \mathrm{~Hz})$ at one of ten radio frequencies (range 165.430-166.063 Hz). This scheme allowed for relatively short loops of scanning across only 10 , rather than 30 , different radio frequencies. This scheme can make it difficult to distinguish individuals if two birds broadcasting on the same radio frequency (but different pulse rates) are detected simultaneously, but this never happened in our study.

In 2005, we placed transmitters on 18 males and $12 \mathrm{fe}-$ males. Fifteen of these were deployed at Tutakoke 4-6 September and 13 at Tutakoke 18-20 September. Two others were placed on birds at Kanaryarmiut on 26 September 2005.

We used a hand-held receiver to test transmitters immediately upon release of birds and subsequently scanned for the transmitters daily 4-9 and 18-23 September at Tutakoke and 10-17 and 24-26 September at Kanaryarmiut-at all dates on which we were at each camp. To allow additional scanning during our intermittent absence from Tutakoke, we placed an automated receiving station in a tower $10 \mathrm{~m}$ high $1 \mathrm{~km}$ WSW of Tutakoke camp between 9 September and 3 October. For further scanning and locating of the transmitter-equipped birds, we made nine aerial surveys on 19, 20, 25, 27, and 30 September and 4, 7, 11, and 26 October from either a Cessna 185 or 206 equipped with VHF receiving antennae, flying at altitudes varying between 180 and $975 \mathrm{~m}$. All surveys were made in the area between $61^{\circ} 10^{\prime}$ and $61^{\circ} 26^{\prime} \mathrm{N}, 165^{\circ} 03^{\prime}$ and $165^{\circ} 42^{\prime} \mathrm{W}$ (approximately $30 \times 35 \mathrm{~km}$; see inset Fig. 1) but did not always cover the entire area.

We assessed the threat of avian predators to the Sharptailed Sandpiper at our main study site, Tutakoke, in both 2005 and 2006 and at Kanaryarmiut Field Station in 2005. We did this by recording all observations of predator/shorebird interactions when we were in the field. Most observations were recorded in conjunction with daily trapping, at the Tutakoke camp and south about $5 \mathrm{~km}$. The area comprises several habitat types used by Sharp-tailed Sandpipers (Handel and Gill 2010). At high tide several thousand small sandpipers, primarily Dunlins (Calidris alpina) but also varying numbers of Rock Sandpipers (C. ptilocnemis) and Western Sandpipers ( $C$. mauri), roost on the immediate coast (Handel and Gill 1992).
Observations were made in 2005 by $\AA \mathrm{L}, \mathrm{RG}, \mathrm{SJ}$, and MK, in 2006 by RG and others (see Acknowledgments). We considered a potential threat to be any avian predator that elicited a response from a shorebird, including not only direct pursuit of shorebirds by predators but also disruptions to roosting and feeding flocks. The latter ranged from birds becoming alert but remaining on the ground to the entire roost or flock flushing and remaining airborne until the threat subsided. In 2005, we did not keep track of observer effort (hours afield), but in 2006 we did. In both years, when we noted a predatorshorebird interaction, we recorded the time, location, potential predator, the species of shorebird involved, its reaction to the predator, and the outcome of the interaction.

There are several empirical and theory-based models from which the flight range of a bird with a given fuel load can be estimated. All, however, require specific values for various physiological, behavioral, and meteorological variables, several or most of which are not normally known, attaching a large degree of uncertainty to any flight-distance estimate. Nevertheless, we ran the program Flight for Windows (version 1.22, Pennycuick 2008) for male and female juvenile Sharptailed Sandpipers separately. We entered the following values (male then female): wing span 0.434 and $0.412 \mathrm{~m}$; wing area 0.0220 and $0.0205 \mathrm{~m}^{2}$; body mass at start 134 and $112 \mathrm{~g}$ (an estimated $100 \%$ fuel load). We measured wing span and wing area according to Pennycuick (2008) on live birds (the average of six males and four females). We assumed a fat fraction of 0.41 and flight altitude of $1500 \mathrm{~m}$, following Gill et al. (2005) in their analysis of distance of Bar-tailed Godwit flights. For all other estimates we used the default values of the program. Gill et al. (2005) argued that a body-drag coefficient of 0.05 (default is 0.1 ) is a value more reasonable for the godwit, a bird with a shape similar to the Sharp-tailed Sandpiper's. We therefore calculated flight range with both values of body-drag coefficient.

\section{STATISTICS}

Statistical tests were carried out in SPSS 14.0 (SPSS, Inc.), except for the discriminant analysis and piecewise linear regression (by nonlinear estimation), which were carried out in Statistica 8.0 (Statsoft, Inc.).

\section{RESULTS}

We processed 129 Sharp-tailed Sandpipers in 2004 and 228 in 2005, making 357 birds available for analyses. All were firstyear birds (juveniles). In 2005, although one bird was trapped 20 August, very few Sharp-tailed Sandpipers were present in the area until 1 September, when large numbers started to arrive. We are confident that our field work coincided with the Sharp-tailed Sandpiper's primary period of migratory fueling in this part of Alaska.

Relatively few birds were trapped in the second half of September in 2005 because the birds started leaving the area and our trapping was hampered by floods. Furthermore, 


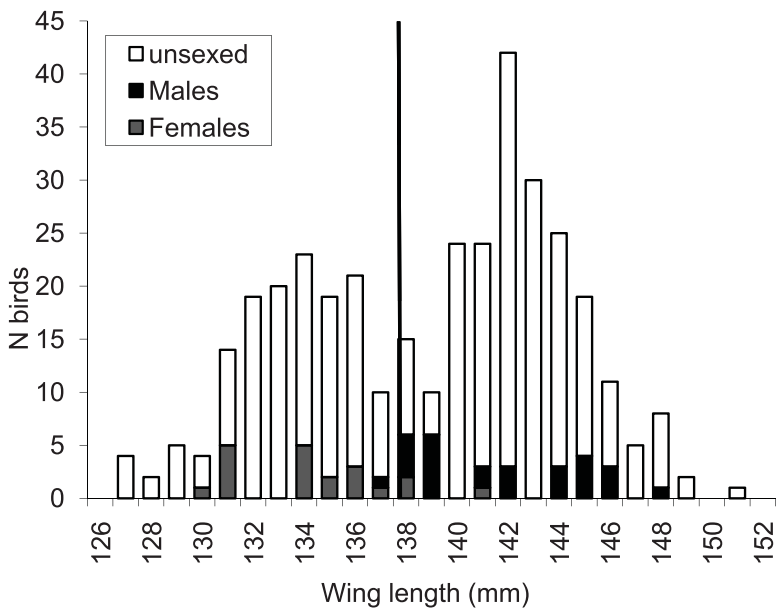

FIGURE 2. Distribution of wing lengths of juvenile Sharp-tailed Sandpipers caught in the central Yukon-Kuskokwim delta in 2004 and 2005, including those sexed genetically (dark bars). The vertical line represents the definition of males and females not genetically sexed.

perhaps in correlation with their increased mass, in late September the birds seemed to become more secretive, spending less time flying around, reducing their exposure to traps and nets.

\section{SEX DETERMINATION AND RATIOS}

Male Sharp-tailed Sandpipers are larger than females, with greater mass and almost no overlap in measurements (Uspenski 1969, Higgins and Davies 1996). Since the body mass of fueling birds is not a reliable predictor of sex, we used wing length instead. On the basis of the distribution of wing lengths, we tentatively sexed birds with wings $\geq 138 \mathrm{~mm}$ as males, those with wings $<138 \mathrm{~mm}$ as females. We then selected 46 birds covering most of the range of wing length to be sexed genetically. Another three birds were included in the genetic analysis because their body masses suggested that our wing-length rule for sexing might have been incorrect (two "females" by wing length were comparatively heavy, and one "male" by wing length was comparatively light).

The genetic sexing largely confirmed our preliminary sexing (Fig. 2). Using discriminant analysis, we identified the separation point between males and females at $137.4 \mathrm{~mm}$. For all three birds that we suspected were erroneously sexed by wing length, the genetic analysis confirmed our suspicions: two males had wing lengths of $137 \mathrm{~mm}$ and one female's wing length was $141 \mathrm{~mm}$. In the primary sample of 46 birds, two would have been incorrectly sexed by wing length: two females had wing lengths of $138 \mathrm{~mm}$. The error of our method is thus on the order of $5 \%$.

It was not possible for us to validate the molecular sexing either physiologically or behaviorally. Because other studies have confirmed that males are considerably larger than females, however, we looked at the molecular sexing of birds in the lowest third of the wing-length range, 127-135 $\mathrm{mm}$.
Among them, 13 out of 13 were genetic females. Similarly, in the highest third of the wing-length range, $143-151 \mathrm{~mm}, 11$ out of 11 birds were genetic males. Errors in the genetic method should be equally likely at any wing length. We therefore conclude that wing length is a very accurate tool for sexing. In the following analyses we sexed birds by wing length $(\geq 138 \mathrm{~mm}$ as male, $<138 \mathrm{~mm}$ as female), except in the five cases where molecular sexing specified otherwise.

Of the 357 birds, 216 were males (60.5\%) and 141 (39.5\%) were females, a sex ratio significantly different from even (binomial test, $P<0.001$ ). This pattern was similar in both years, with 59 and $61 \%$ of the population consisting of males in 2004 and 2005, respectively. For both sexes the median date of trapping was 7 September ( $U$-test, $z=1.683, P=0.92)$. Of the 357 birds, 37 were trapped at the inland sites. The two sexes were equally distributed between inland and coastal sites $\left(\chi_{1}^{2}=0.3\right.$, not significant).

\section{LENGTH OF STAY OF RADIO-TAGGED BIRDS}

Of the 30 birds deployed with a radio transmitter only three were never recorded again and thus apparently staged for 0 days (Fig. 3). One transmitter was recorded until as late as 26 October, but the small distances of $2.5 \mathrm{~km}$ between the aerial fixes indicated that the bird might have been dead or the transmitter might have fallen off as early as 30 September. We excluded data from this bird from further analysis. The median minimum length of stay of the remaining birds $(n=29)$ was 12 days, maximum 33 days.

Within each of the first and second batches of radiotagged birds (14 tagged 3-5 September and 13 tagged 18-20 September), there were no significant correlations between length of stay and any of the variables measured at tagging (mass, fat, wing length, tarsus, total head, Pearson correlation, $P>0.1$ in all cases).

\section{RATE OF FUEL DEPOSITION}

Both fat score and body mass increased throughout the study period (Fig. 3), and fat score was a good predictor of body mass (Pearson regression, $r_{207}=0.91$ in males and $r_{132}=0.87$ in females, $P<0.001$ in both cases).

Within the dates common to both years (1-12 September), a general linear model showed no effect of year on mass $\left(F_{1,299}=\right.$ $0.7, P=0.41)$ after correction for date and sex. There was a marked increase in the rate of fuel deposition around 13 September (Fig. 3). We used a piecewise linear regression to fit two regression lines through the body-mass data for males and females separately, using nonlinear estimation, which also allowed us to estimate the inflection point (day in September: $12.4 \pm$ 0.7 (SE) and 13.0 \pm 1.0 for males and females, respectively).

In the period 1-12 September the slope of mass on date was $0.4 \pm 0.2 \mathrm{~g} \mathrm{day}^{-1}$ for males $(n=179, P=0.07)$ and $0.3 \pm 0.2 \mathrm{~g} \mathrm{day}^{-1}$ for females $(n=124, P=0.10)$, so the rate of daily body-mass increase was only marginally different from zero. In the period 

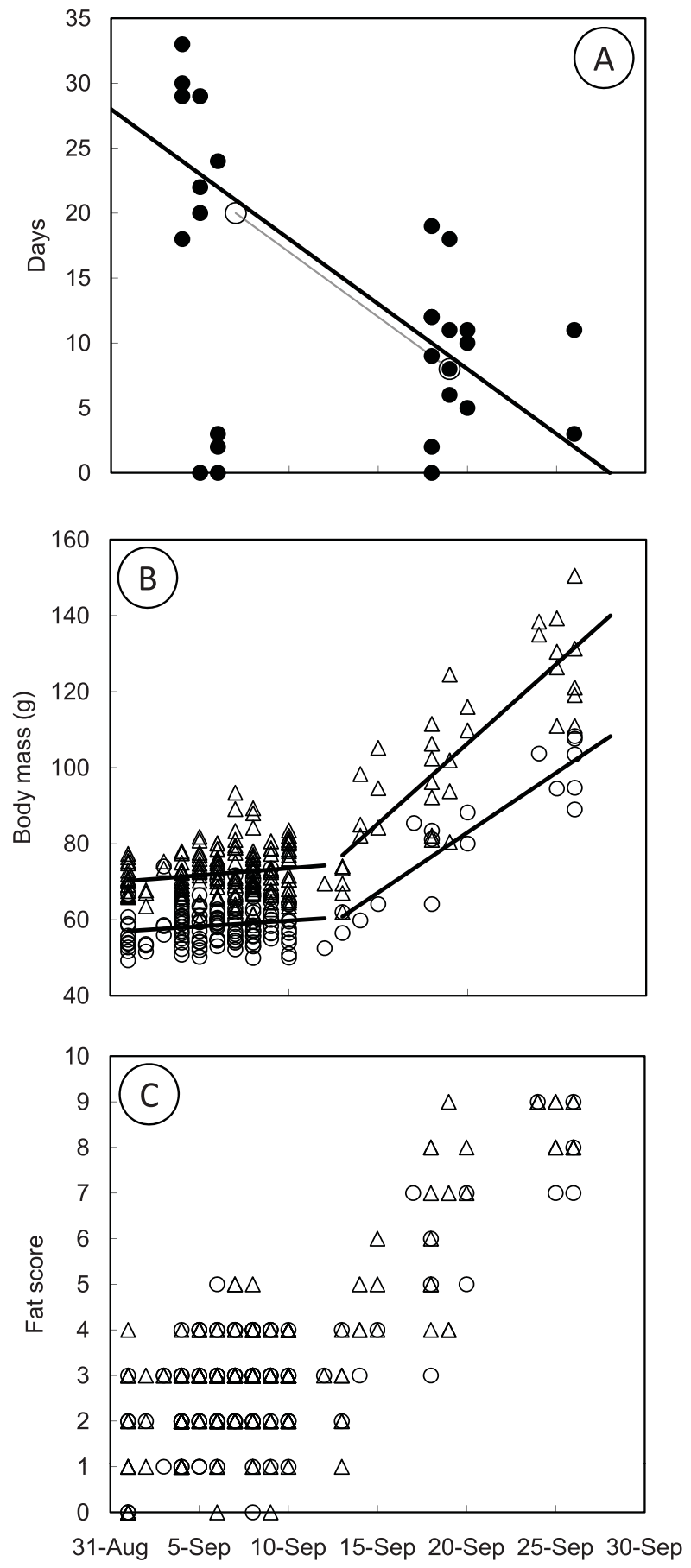

FIGURE 3. Occurrence and fattening of Sharp-tailed Sandpipers in the central Yukon-Kuskokwim delta. (A) Length of stay of radio-tagged birds in relation to date of attachment of the transmitter. The two circles denote a bird initially captured on 7 September and then recaptured on 19 September, when it was equipped with a radio transmitter (it was the only one of the three retrapped bird that had a radio transmitter). To highlight the synchronization in timing of individual birds and that the population is largely closed (see Discussion), the thick line represents the expected relationship between date of attachment of the transmitter and length of stay, should the
13-26 September, however, the slope of mass on date (linear regression) was $4.2 \pm 0.3 \mathrm{~g} \mathrm{day}^{-1}$ for males $(n=36, P<0.001)$ and $3.2 \pm 0.3 \mathrm{~g} \mathrm{day}^{-1}$ for females $(n=17, P<0.001)$. It should be noted that the period 13-26 September represents data from one year almost exclusively (for 13 September there are data for 2004 only; for 14-26 September all data are from 2005).

If we assume a lean body mass of $67 \mathrm{~g}$ for males and $56 \mathrm{~g}$ for females (the average mass of birds with fat scores $0-1$, with a range of 61.4-76.0 $\mathrm{g}$ for males and 49.9-64.0 $\mathrm{g}$ for females), in early September (1-12) males added fuel at a rate of $0.6 \%$ lean body mass day ${ }^{-1}$, females at $0.5 \%$ day $^{-1}$. In late September (13-26), however, these rates amounted to 6.3\% (males) and $5.7 \%$ (females) day ${ }^{-1}$.

In 2005, we retrapped three birds, all females according to wing length, 2, 4, and 12 days, respectively, after they had been banded. One had decreased $2.3 \mathrm{~g}$ in 2 days (7-9 September) and another had increased $2.9 \mathrm{~g}$ in 4 days (5-9 September). Such short-term drops in body mass within a day or two of first capture are well known in studies of birds' stopovers. They probably relate directly or indirectly to the handling during banding (Lindström 1995, Atkinson et al. 2007). The third bird was banded 7 September weighing $63.0 \mathrm{~g}$ and recaptured on 19 September weighing $85.0 \mathrm{~g}$, an increase of $22 \mathrm{~g}$ in 12 days $\left(1.8 \mathrm{~g} \mathrm{day}^{-1}\right.$ or $3.6 \%$ of lean body mass day $\left.{ }^{-1}\right)$, very similar to the predicted mass increase of $23.9 \mathrm{~g}(0.3 \times 5+$ $3.2 \times 7$ ) over the 12 days between captures.

\section{AMOUNT OF FUEL DEPOSITED}

Upon arrival in early September, most birds carried only small fuel loads. The 118 birds trapped 1-5 September had a median fat score of 2 (range $0-4$ in both sexes) and average body masses of $70.8 \mathrm{~g}$ for males and $57.6 \mathrm{~g}$ for females. These values represent fuel loads of about 3-6\% above lean body mass. Obviously, juvenile Sharp-tailed Sandpipers arrive in Alaska with very small fuel stores.

In contrast, the latest 18 birds (trapped 24-26 September) had a median fat score of 8 and mean body masses of $128.5 \mathrm{~g}$ for males $(n=11), 100.2 \mathrm{~g}$ for females $(n=7)$. This difference corresponds to fuel loads of $92 \%$ and $79 \%$ of lean body mass, respectively. The masses of the heaviest birds, a $150.5-\mathrm{g}$ male and a 108.3-g female (Fig. 3), indicate fuel loads equal to $125 \%$ and $93 \%$ of lean body mass, respectively.

birds fuel up until reaching an average fuel load of $100 \%$. From the data presented $(\mathrm{C})$, the predicted average departure date is $28 \mathrm{Sep}$ tember. Transmitter deployment on 28 September should thus result in an expected staging duration of 0 days; deployment $x$ days before 28 September should result in an expected staging duration of $x$ days. (B) Body mass of male (triangles) and female (circles) sandpipers in relation to date of capture in 2004 (data collected until 13 September only) and 2005. Lines of stepwise linear regression (see text) are drawn for males and females separately. (C) Fat scores (scale 0-9) of juvenile males (triangles) and females (circles). 


\section{FLIGHT-RANGE ESTIMATES}

The estimated distances of flight in still air were close to $7100 \mathrm{~km}$ for both males and females. With a body-drag coefficient of 0.05 (see Methods), the predicted capacity of flight in still air of both sexes of the Sharp-tailed Sandpiper is around $9800 \mathrm{~km}$.

\section{PREDATION DANGER}

We observed eight species of potential avian predator during 2005 and 2006 (in decreasing frequency): the Parasitic Jaeger (Stercorarius parasiticus), Northern Harrier (Circus cyaneus), Peregrine Falcon (Falco peregrinus), Gyrfalcon ( $F$. rusticolus), Glaucous Gull (Larus hyperboreus), Merlin ( $F$. columbarius), Short-eared Owl (Asio flammeus), and Longtailed Jaeger ( $S$. longicaudus). Combined, they accounted for 61 observed interactions with shorebirds, 45 (74\%) involving Parasitic Jaegers, 8 (13\%) Northern Harriers, and 4 (7\%) Peregrine Falcons. In 2006, the year we recorded observer effort, shorebirds and predators interacted at a rate of $0.07 \mathrm{hr}^{-1}$. Both values are roughly equal to one observed predator-prey interaction per day of field work. In 2006, shorebirds' resulting mortality rate was $0.02 \mathrm{hr}^{-1}$, roughly one shorebird killed every 3 days. We observed seven events that ended in mortality, five by Parasitic Jaegers and two by Glaucous Gulls. The Glaucous Gull is likely not a serious predator of small shorebirds during the autumn staging period. Both instances of predation by gulls involved gulls hunting along the shoreline, where they found Dunlins or Rock Sandpipers that were likely injured during our trapping. We identified four of the prey as Dunlins; none of the others could positively be identified as Sharp-tailed Sandpipers.

\section{DISCUSSION}

As outlined in the Introduction, there are several costs associated with migratory detours, related to time, energy, and orientation, suggesting that detours should be selected against. In the case of the detour made by juvenile Sharp-tailed Sandpipers there obviously must be benefits exceeding these costs.

\section{FUEL DEPOSITION AND LENGTH OF STAY}

The rate of fueling of free-living individual birds can be estimated in two ways, either by retrapping individual birds or by the average change in mass of the population as a whole (Lindström and Piersma 1993). Ideally, the latter method requires that the population be closed, that is, all of the members of a population at any given site arrive and depart at the same time. Because we retrapped too few birds to evaluate mass change by individuals, we derived a population-based estimate of fueling rates.

By deploying and detecting radio transmitters on a number of birds, we determined individuals' minimum length of stay. Plotting minimum length of stay against date of deployment (Fig. 3A) confirms the impression that most birds arrived within a small interval in early September and stayed in the area until the end of September. Assuming that the birds stayed in the area until they reached an average fuel load of $100 \%$ (the approximate fuel load of the birds we trapped late in September), we expected an average day of departure of 27 and 29 September for males and females, respectively, which is in agreement with the observations of apparent duration of staging with respect to date of deployment of the transmitter (Fig. 3).

Six of the 30 birds apparently left the area within $0-3$ days of capture. At the average fueling rates we calculated, such short length of stay would not have provided those individuals time to achieve a mass sufficient for departure. One possibility is that these birds were transients that left our study area to accumulate their fat reserves elsewhere, that is, our population is not completely closed. We cannot exclude our methods as causes of the short apparent stays, for example, that some radios failed prematurely or birds left prematurely because of our handling. Overall, however, the transmitter data indicated that a sufficient proportion of the Sharp-tailed Sandpipers stayed long enough in our study area for us to use the birds' average mass change as an estimate of fuel-deposition rate (cf. Lindström and Piersma 1993).

Body mass increased over the whole period, as did the amount of visible fat, indicating that a large part of the mass increase was due to fat deposition. The increase in mass seemed to be divided into two periods. Until 12 September, the average mass increased only slowly $(0.5-0.6 \%$ of lean body mass day $\left.^{-1}\right)$. The fuel-deposition rate increased sharply in the second half of September, averaging about $6 \%$ of lean body mass day $^{-1}$. According to Lindström's (2003) review of maximum rates of fuel deposition in migrating birds (based on field data), at the population level the rate expected for similar-sized migrants is $3.0-3.3 \%$ of lean body mass day ${ }^{-1}$. Handel and Gill (2010) analyzed body-mass data on Sharp-tailed Sandpipers from the whole of southwestern Alaska and found an average of $1.0 \%$ of lean body mass day ${ }^{-1}$ from mid August to late October. The discrepancy between these findings may be a result of the heterogeneity in Handel and Gill's (2010) data set, which includes birds at multiple sites over multiple years, possibly leading to a less accurate estimate of mean fueling rates. It should be noted that Handel and Gill (2010) also found many birds with body masses $>100 \mathrm{~g}$, suggesting that the kind of fueling we recorded takes place at other sites in Alaska as well.

Among the ten species of shorebirds whose lean body mass ranges from 40 to $65 \mathrm{~g}$ and in which high fueling rates have been found, only the Dunlin (lean body mass $40 \mathrm{~g}$ ) along the German coast of the North Sea was found to have a higher population fueling rate, $8.5 \%$ of lean body mass day ${ }^{-1}$ (Dierschke 1998, Lindström 2003). This rate is still lower, however, than the average of $9.6 \%$ of lean body mass day ${ }^{-1}$ found in 15 species of similar-sized shorebirds fed ad libitum in captivity during the fall migration season (Kvist and Lindström 2003). The latter value is probably close to the physiological maximum 
rate achievable under ideal conditions. Nevertheless, the fueldeposition rate achieved at our Alaskan study site, $6 \%$ of lean body mass day ${ }^{-1}$, is among the highest found in a wild migratory shorebird.

Lindström et al. (2010) also found two apparent phases of fuel deposition in adult European Golden-Plovers (Pluvialis apricaria) on fall migration in Sweden, where the shift from slow to fast fueling coincided with the termination of primary molt. The juvenile Sharp-tailed Sandpipers were not molting. Whether internal processes, such as rebuilding organs involved in the digestion of food (Jehl 1997, Piersma and Lindström 1997), prevent fast fueling upon the birds' arrival in Alaska, or whether external factors such as temporal changes in food availability or predation danger are at play, awaits further investigations.

During fall migration, fuel loads deposited by shorebirds breeding in the Arctic vary by species, age class, and stage of migration. During the first stages of southward migration over the tundra, juveniles of several species rarely add more fuel than $10 \%$ of their lean body mass (Lindström 1998, Tulp et al. 2000, Lindström et al. 2002). Although we do not know the fuel stores of Sharp-tailed Sandpipers when they leave Siberia, the birds are quite lean by the time they arrive in Alaska. Farther south, most shorebirds breeding in the Arctic (juveniles as well as adults) migrate with fuel stores $20-70 \%$ above lean body mass (Alerstam and Lindström 1990), although fuel loads up to $100 \%$ of lean body mass are found in some species making long nonstop flights (Jehl 1979, McNeil and Cadieux 1972, Page and Middleton 1972, Harrington et al. 1991, Piersma and Gill 1998, Gill et al. 2009).

Lean body mass varies individually, and the heaviest male and female Sharp-tailed Sandpipers we studied may well have had lean body masses above 67 and $56 \mathrm{~g}$, respectively, leading to an overestimate of fuel stores in the heaviest birds. If their lean body mass was $71 \mathrm{~g}$, the highest mass of birds with fat scores 0 or 1 , the three heaviest birds had fuel loads of at least 95,96 , and $112 \%$ of lean body mass. Combining the bodymass data of captured birds with the duration of staging of transmitter-equipped birds in relation to date (Fig. 3) suggests that many birds stay in the area until late September and leave with fuel loads close to $100 \%$ of lean body mass.

From the distribution of fall observations of juvenile Sharp-tailed Sandpipers in the Pacific region, Handel and Gill (2010) argued that a large proportion of the birds fly directly from Alaska across the Pacific to Australia, an estimated distance of flight in still air close to $7100 \mathrm{~km}$. With a body-drag coefficient of 0.05 (see Methods), both sexes of the Sharptailed Sandpiper have a predicted flight capacity of around $9800 \mathrm{~km}$, a value close to that of the direct great-circle route from Alaska to Australia (Fig. 3). In addition, birds could gain extra distance by making use of favorable winds during part of the trans-oceanic flight (cf. Gill et al. 2009). Given the large uncertainties in flight-distance models, the strongest support for a nonstop flight to Australia may nevertheless come from a comparison with Bar-tailed Godwits that have been proven to make nonstop trans-Pacific flights even longer than those suggested for the Sharp-tailed Sandpiper (Gill et al. 2009). Like the Sharp-tailed Sandpipers we studied, Bar-tailed Godwits also double their mass prior to their nonstop flight from Alaska to New Zealand (Piersma and Gill 1998), and their aspect ratios are similarly very high, 9.3 in the Bar-tailed Godwit (Gill et al. 2005) and 8.5 in the Sharp-tailed Sandpipers (this study). A high aspect ratio implies long, narrow wings and therefore energy-efficient flight. Juvenile Sharp-tailed Sandpipers most likely have the capacity to fly nonstop from Alaska to Australia, but firm evidence for such long flights is still needed.

\section{PREDATION DANGER}

Danger of predation is an important factor contributing to the relative value of migratory shorebirds' stopover and staging sites (Lindström 1989, Alerstam and Lindström 1990, Ydenberg et al. 2004, Pomeroy et al. 2008). Gill et al. (2009) reported predators to be fewer in our study area in the YukonKuskokwim delta than at other sites for shorebirds in Alaska. During our field work in the central delta we also got the impression that this area supports a relatively low density of predators. Overall, one observed predator-prey interaction per field day, or one shorebird killed per three field days, is comparatively low. For example, Dekker and Ydenberg (2004) reported rates of 0.7 attacks $\mathrm{hr}^{-1}$ of the Peregrine Falcon on Dunlins wintering in British Columbia, a rate $10 \times$ higher than we recorded for all predators combined. Although our observations are insufficient for decisive conclusions about the role of predation on the evolution of the migratory detour of juvenile Sharp-tailed Sandpipers to Alaska, they provide an important impetus for future work.

\section{THE AGE-SPECIFIC DETOUR TO ALASKA}

From a meta-analysis of bird counts and observations in the whole Pacific region, Handel and Gill (2010) convincingly argued that juvenile Sharp-tailed Sandpipers' principal route of migration goes via Alaska. As outlined in our introduction, there are several reasons to expect natural selection to act against such detours. The other well-documented case of a distinct age-specific migration route is of the Honey Buzzard (Pernis apivorus). On their migration through Europe in fall, the adults make a detour via Gibraltar, whereas juveniles fly a more direct route over the Mediterranean Sea toward the winter range (Schmid 2000, Hake et al. 2003). Schmid (2000) suggested that the difference may be caused by seasonal variation in flight conditions, with favorable thermals being less available to juveniles, which migrate later in fall. Another case, but less well described, may be the fall migration of Dunlins from northeastern to western Europe. Leslie and Lessells (1978) suggested that most juvenile Dunlins fly 
around the coast of northern Norway, whereas adults migrate mainly through the Baltic basin.

Factors other than thermal flight dynamics must provide the selective basis for juvenile Sharp-tailed Sandpipers' migration pattern. On the basis of Alerstam's (2001) evaluation of detours in bird migration, we predicted that in Alaska juvenile Sharp-tailed Sandpipers should have very high rates of fuel deposition. Our data confirmed that prediction, providing a compelling benefit for the long detour. Still, when alternative routes exist, an understanding of the preferred alternative can be obtained only by comparing the ecological conditions along the alternative flyways and how these change over time, since change over time in conditions for fueling and predation may have important consequences for the optimal choice (e.g., Ydenberg et al. 2007). Currently, we do not know the fuel-deposition and predation rates for adult and juvenile Sharp-tailed Sandpipers along the west-Pacific flyway. For the adults, migrating about a month earlier than juveniles, we also need to learn the fueling and predation rates if they would take the Alaskan detour at that time of year.

Another contributing factor to the age difference in migration strategy could be different fitness consequences for juveniles and adults of a timely arrival at the terminus of migration. For example, on the nonbreeding grounds adult Sharp-tailed Sandpipers may be under greater selective pressure for an early molt than are juveniles, as suggested by Handel and Gill (2010).

Differences in tradeoffs similar to those between age classes may also exist between the sexes within an age class. In our sample, we observed an apparent bias toward males $(60 \%)$. Handel and Gill (2010) found a ratio of $56 \%$ males. Although, in contrast to our estimate, their ratio was not significantly different from $50 \%$, it is close to our ratio of $60 \%$, and there is no statistical difference between the two $\left(\chi_{1}^{2}=\right.$ $0.86, P=0.36)$. Higgins and Davies (1996) presented data on Sharp-tailed Sandpipers banded in Australia, and there seems to be no significant prevalence of males there. Being the larger sex, males may have a longer flight range (McWilliams et al. 2004) and may thus be more able to make a long detour en route to the nonbreeding grounds than can females (cf. O'Hara et al. 2006). Handel and Gill (2010) concluded that juvenile Sharp-tailed Sandpipers' principal route of migration goes via Alaska but that some follow the west-Pacific flyway. It would be interesting to know whether females are overrepresented among the juvenile Sharp-tailed Sandpipers following the west-Pacific flyway in the wake of their parents.

Gill et al. (2009) suggested that the seemingly insuperable task of crossing the Pacific Ocean could actually be considered an opportunity rather than a barrier for capable long-distance flyers. By embarking on such a flight, migrating shorebirds can experience a largely wind-assisted passage relatively free of pathogens and predators. We conclude that the very high fueling rates juvenile Sharp-tailed Sandpipers achieve in coastal Alaska are in agreement with the theoretical expectations for the evolution of migratory detours (Alerstam 2001), but other advantages might also accrue as a result of this strategy. It remains an exciting possibility that a long trans-oceanic flight after staging in western Alaska might add benefits to an already intriguing detour.

\section{ACKNOWLEDGMENTS}

This project was part of the "Beringia 2005" expedition organized by the Swedish Polar Research Secretariat, to which we are most grateful. We thank Mike Rearden of the U.S. Fish and Wildlife Service in Bethel and his personnel for their superb logistic and moral support. Additional logistic and financial support was kindly provided by the U.S. Geological Survey, Alaska Science Center, Anchorage, the Dutch Science Foundation (NWO-NAP), the Royal Physiographic Society in Lund, and Environment Canada. Several people helped substantially in the field, including Martin Green, Phil Battley, Nils Warnock, Jesse Conklin, Patrick Lemons, David Melville, James Luown, Ty Donnelly, and Anders Wirdheim. George Walters, Robert Sundown, Mike Rearden, Fred Broerman, and Isaac Bedingfield assisted in aerial radio telemetry, John Terenzi helped with wing-area estimates, and Raymond Klaassen assisted with flight-distance calculations. We thank Staffan Bensch, Martin Green, and two anonymous reviewers for comments on earlier versions of the manuscript. Any use of trade, product, or firm names in this publication is for descriptive purposes only and does not imply endorsement by any author's affiliation. This is publication 4926 of the Netherlands Institute of Ecology.

\section{LITERATURE CITED}

Alatalo, R. V., AND A. LundBerg. 1986. Heritability and selection on tarsus length in the Pied Flycatcher (Ficedula hypoleuca). Evolution 40:574-583

Alerstam, T. 1990. Bird migration. Cambridge University Press, Cambridge, England.

Alerstam, T. 2001. Detours in bird migration. Journal of Theoretical Biology 209:319-331.

Alerstam, T., AND Å. Lindström. 1990. Optimal bird migration: the relative importance of time, energy and safety, p. 331-351. In E. Gwinner [ED.], Bird migration: the physiology and ecophysiology. Springer-Verlag, Berlin.

Alerstam, T., G. A. Gudmundsson, M. Green, and A. HedenSTRÖM. 2001. Migration along orthodromic sun compass routes by arctic birds. Science 291:300-303.

Atkinson, P. W., A. J. Baker, K. A. Bennett, N. A. Clark, J. A. Clark, K. B. Cole, A. Dekinga, A. Dey, S. Gillings, P. M. GonzÁlez, K. Kalasz, C. D. T. Minton, J. Newton, L. J. Niles, T. Piersma, R. A. Robinson, And H. P. Sitters. 2007. Rates of mass gain and energy deposition in Red Knot on their final spring staging site is both time- and condition-dependent. Journal of Applied Ecology 44:885-895.

Battley, P. F., T. Piersma, M. W. Dietz, S. Tang, A. Dekinga, And K. Hulsman. 2000. Empirical evidence for differential organ reductions during trans-oceanic bird flight. Proceedings of the Royal Society of London B 267:191-195.

BÉLISLE, M., AND J.-F. GIROUX. 1995. Predation and kleptoparasitism by migrating Parasitic Jaegers. Condor 97:771-781.

Burns, J. G., AND R. C. YDEnBerG. 2002. The effects of wing loading and gender on the escape flights of Least Sandpipers (Calidris minutilla) and Western Sandpipers (Calidris mauri). Behavioural Ecology and Sociobiology 52:128-136. 
DEKKER, D., AND R. YDENBERG. 2004. Raptor predation on wintering Dunlins in relation to the tidal cycle. Condor 106:415-419.

DierschKe, V. 1998. High profit at high risk for juveniles Dunlins, Calidris alpina, stopping over at Helgoland (German Bight). Ardea 86:59-69.

GiLl, R. E. JR., AND C. M. HANDEL. 1981. Shorebirds of the eastern Bering Sea, p. 719-730. In D. W. Hood and J. A. Calder [EDS.], Eastern Bering Sea shelf: oceanography and resources. Vol. 2. University of Washington Press, Seattle.

GiLL, R. E. JR., AND C. M. HANDEL. 1990. The importance of subarctic intertidal habitats to shorebirds: a study of the central YukonKuskokwim Delta, Alaska. Condor 92:709-725.

Gill, R. E. JR., T. Piersma, G. Hufford, R. Servranckx, And A. RIEGEN. 2005. Crossing the ultimate ecological barrier: evidence for an 11 000-km long nonstop flight from Alaska to New Zealand and eastern Australia by Bar-tailed Godwits. Condor 107:1-20.

Gill, R. E. JR., T. L. TibBitTs, D. C. Douglas, C. M. Handel, D. M. Mulcahy, J. C. Gottschalck, N. Warnock, B. J. McCafFERY, P. F. BATtLey, AND T. Piersma. 2009. Extreme endurance flights by landbirds crossing the Pacific Ocean: ecological corridor rather than barrier? Proceedings of the Royal Society of London B 276:447-458.

Green, G. H. 1980. Total head length. Wader Study Group Bulletin 29:18.

Griffiths, R., M. C. Double, K. OrR, and R. J. G. Dawson. 1998. A DNA test to sex most birds. Molecular Ecology 7:1071-1075.

Gudmundsson, G. A., Å. Lindström, and T. Alerstam. 1991. Optimal fat loads and long-distance flights by migrating Knots Calidris canutus, Sanderlings C. alba and Turnstones Arenaria interpres. Ibis 133:140-152.

Hake, M., N. Kuellén, and T. Alerstam. 2003. Age-dependent migration strategy in Honey Buzzards Pernis apivorus tracked by satellite. Oikos 103:385-396.

HANDEL, C. M., AND R. E. GiLl JR. 1992. Roosting behavior of premigratory Dunlins (Calidris alpina). Auk 109:57-72.

HANDEL, C. M., AND R. E. Gill JR. 2010. Wayward youth: transBeringian movement and differential southward migration by juvenile Sharp-tailed Sandpipers. Arctic 63:273-288.

Harrington, B. A., F. J. Leeuwenberg, L. S. Resende, R. McNeil, B. T. Thomas, J. S. Grear, and E. F. Martinez. 1991. Migration and mass change of White-rumped Sandpipers in North and South America. Wilson Bulletin 103:621-636.

Higgins, P. J., AND S. J. J. F. Davies [eDS.]. 1996. Handbook of Australian, New Zealand and Antarctic birds. Vol. 3. Snipes to pigeons. Oxford University Press, Melbourne.

JeHL, J. R. JR. 1979. The autumnal migration of Baird's Sandpiper. Studies in Avian Biology 2:55-68.

JEHL, J. R. JR. 1997. Cyclical changes in body composition in the annual cycle and migration of the Eared Grebe Podiceps nigricollis. Journal of Avian Biology 28:132-142.

Kessel, B., AND D. Gibson. 1978. Status and distribution of Alaska birds. Studies Avian Biology 1.

KolthofF, G. 1896. Zur Herbstwanderung der nordischen Sumpfvögel über die Insel Öland. Festschrift Wilhelm Lilljeborg, Uppsala, Sweden.

KullberG, C., T. Fransson, and S. JakobSSOn. 1996. Impaired predator evasion in fat Blackcaps (Sylvia atricapilla). Proceedings of the Royal Society of London B 263:1671-1675.

KVIST, A., AND Å. LiNDSTRÖM. 2003. Gluttony in migratory wadersunprecedented energy assimilation rates in vertebrates. Oikos 103:397-402.

LANK, D. B., AND R. C. YDENBERG. 2003. Death and danger at migratory stopovers: problems with "predation risk." Journal of Avian Biology 34:225-228.
Leslie, R., AND C. M. Lessells. 1978. The migration of Dunlin Calidris alpina through northern Scandinavia. Ornis Scandinavica 9:84-86.

LiNDSTRÖM, Å. 1989. Finch flock size and risk of hawk predation at a migratory stopover site. Auk 106:225-232.

LINDSTRÖM, Å. 1995. Stopover ecology of migrating birds: some unsolved questions. Israel Journal of Zoology 41:407-416.

LiNDSTRÖM, A. 1998. Mass and morphometrics of Little Stints Calidris minuta on autumn migration along the arctic coast of Eurasia. Ibis 140:171-174.

LinDSTRÖM, Å. 2003. Fuel deposition rates in migrating birds: causes, constraints and consequences, p. 307-320. In P. Berthold, E. Gwinner and E. Sonnenschein [EDS.], Avian migration. Springer-Verlag, Berlin.

Lindström, Å., J. Dänhardt, M. Green, R. KlaAssen, and P. OlsSON. 2010. Can intensively farmed arable land be favourable for birds during migration? The case of the Eurasian Golden Plover Pluvialis apricaria. Journal of Avian Biology 41:154-162.

Lindström, Å., M. KlaAssen, AND R. LANCTOT. 2005. The foldable "Ottenby" walk-in trap: a handy and efficient wader trap for expedition conditions. Wader Study Group Bulletin 150:50-53.

LindSTRÖM, Å., AND T. PIERSMA. 1993. Mass changes in migrating birds: the evidence for fat and protein storage re-examined. Ibis 135:70-78

Lindström, Å., M. Klaassen, T. Piersma, N. Holmgren, and L. WeNNERBERG. 2002. Fuel stores of juvenile waders on autumn migration in high arctic Canada. Ardea 90:93-101.

MCCAFFerY, B. J., J. van DE KAM, AND K. WoOdLey. 2008. Observations of Red Knots Calidris canutus at Old Chevak, YukonKuskokwim Delta, Alaska, spring 2008. Wader Study Group Bulletin 115:167-170.

McNeil, R., AND F. CAdieux. 1972. Fat content and flight-range capabilities of some adult spring and fall migrant North American shorebirds in relation to migration routes on the Atlantic coast. Naturaliste Canadien 99:589-605.

McWilliams, S. R., C. Guglielmo, B. Pierce, and M. Klaassen. 2004. Flying, fasting, and feeding in birds during migration: a nutritional and physiological ecology perspective. Journal of Avian Biology 35:377-393.

Nebel, S., AND B. J. McCAffery. 2003. Vocalisation activity of breeding shorebirds: documentation of its seasonal decline and applications for breeding bird surveys. Canadian Journal of Zoology 81:1702-1708.

O'Hara, P. D., G. Fernandez, B. HaAse, H. de la Cueva, and D. B. LANK. 2006. Differential migration in Western Sandpipers with respect to body size and wing length. Condor 108:225-232.

Page, G., And A. L. A. Middleton. 1972. Fat deposition during autumn migration in the Semipalmated Sandpiper. Bird-Banding 43: 85-96.

Pennycuick, C. J. 2008. Modeling the flying bird. Elsevier, Amsterdam.

PetTersson, J., AND D. HAsSELQUist. 1985. Fat deposition and migration capacity of Robins Erithacus rubecula and Goldcrests Regulus regulus at Ottenby, Sweden. Ringing \& Migration 6:66-76.

PIERSMA, T. 1984. International wader migration studies along the East Atlantic Flyway during spring 1985. Wader Study Group Bulletin 42:5-9.

Piersma, T., AND R. E. Gill JR. 1998. Guts don't fly: small digestive organs in obese Bar-tailed Godwits. Auk 115:196-203.

Piersma, T., AND Å. Lindström. 1997. Rapid reversible changes in organ size as a component of adaptive behavior. Trends in Ecology \& Evolution 12:134-138.

Pomeroy, A. C., D. A. Acevedo Seaman, R. W. Butler, R. W. Elner, T. D. Williams, and R. C. YDEnBerg [online]. 2008 Feeding-danger trade-offs underlie stopover site selection by 
migrants. Avian Conservation and Ecology 3(1): 7. <http://www. ace-eco.org/vol3/iss1/art7/>.

RickberG, S. 2006. (ED.) Yearbook 2005. Swedish Polar Research Secretariat, Stockholm.

SCHMID, H. 2000. Getrennte Wege: Der Herbstzug von juvenilen und adulten Wespenbussarden Pernis apivorus - eine Synthese. Ornitologische Beobachter 97: 191-222.

ToMKOVICH, P. S. 1992. Breeding-range and population changes of waders in the former Soviet Union. British Birds 85:344-365.

Tulp, I., H. Schekkerman, and R. Klaassen. 2000. Studies on breeding shorebirds at Medusa Bay, Taimyr, in summer 2000. Alterra-report 219. Alterra, Wageningen, the Netherlands.
UsPENSKI, S. M. 1969. Die Strandläufer Eurasiens (Gattung Calidris). Neue Brehm-Bücherei no. 420. Westarp Wissenschaftenverlagsgesellschaft, Wittenberg, Germany.

YDENBerg, R. C., R. W. Butler, AND D. B. LANK. 2007. Effects of predator landscapes on the evolutionary ecology of routing, timing and molt by long-distance migrants. Journal of Avian Biology 38:523-529.

Ydenberg, R. C., R. W. Butler, D. B. Lank, B. D. Smith, and J. IRELAND. 2004. Western Sandpipers have altered migration tactics as Peregrine Falcon populations have recovered. Proceedings of the Royal Society of London B 271:1263-1269. 